\title{
Stratigraphy of the Chattanooga
}

Shale (Upper Devonian and Lower Mississippian) in Vicinity of Big Stone Gap, Wise County, Virginia

G E O L O G I C A L S U R V E Y B U L L E T I N 14999

Prepared in cooperation with the U.S. Department of Energy

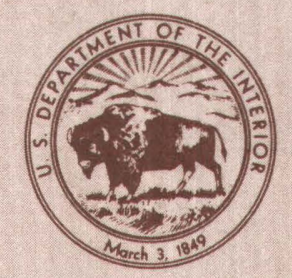





\section{Stratigraphy of the Chattanooga Shale (Upper Devonian and Lower Mississippian) in Vicinity of Big Stone Gap, Wise County, Virginia}

By ROY C. KEPFERLE, PAUL EDWIN POTTER, and WAYNE A. PRYOR With a section on PETROLOGY By THOMAS V. STENBECK

G E O L O G I C A L S U R V E Y B U L L E T I N 1499

Prepared in cooperation with the U.S. Department of Energy

A lithic description and gamma-ray log of a classic outcrop section provide a basis for correlation with subsurface units

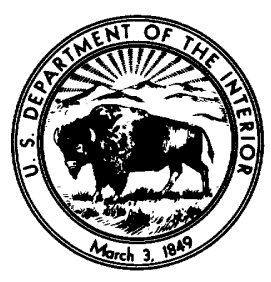


UNITED STATES DEPARTMENT OF THE INTERIOR

JAMES G. WATT, Secretary

GEOLOGICAL SURVEY

Doyle G. Frederick, Acting Director

\section{Library of Congress Cataloging in Publication Data}

Kepferle, Roy Clark, 1926-

Stratigraphy of the Chattanooga Shale (Upper Devonian and Lower Mississippian) in vicinity of Big Stone Gap, Wise County, Virginia.

(Geological Survey bulletin ; 1499)

Bibliography: $p$.

Supt. of Docs. no.: I 19.3:1499

1. Geology, Stratigraphic-Devonian. 2. Geology, Stratigraphic-Mississippian.

3. Shale-Virginia-Big Stone Gap region. 4. Geology-Virginia-Big Stone Gap region. I. Potter, Paul Edwin, joint author. II. Pryor, Wayne Arthur, joint author. III. United States. Dept. of Energy. IV. Title. V. Series: United States, Geological Survey. Bulletin ; 1499.

QE75.B9 no. 1499 [QE672] 557.3s $\left(551.7^{\prime} 4\right] \quad 80-607062$ 


\section{CONTENTS}

Abstract - - 1

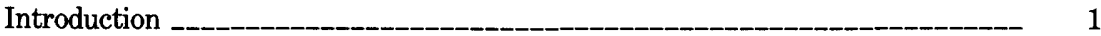

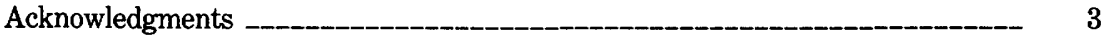

Description and interpretation of the section ______________________ 5

Method _-- 5

Description - 6

Sunbury Shale _--_-_-_-_- 9

Bedford Shale and contorted zone

Cleveland Member and Three Lick Bed of Ohio Shale

Huron Member of Ohio Shale __________________- 12

Joints

Petrology, by Thomas V. Stenbeck _-_____________________ 13

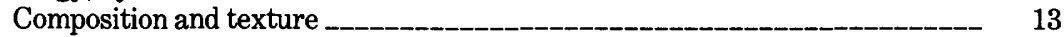

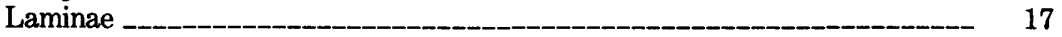

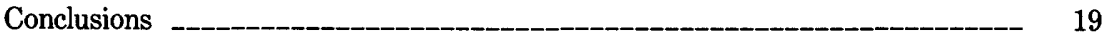

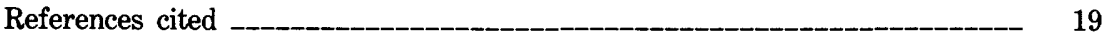

\section{ILLUSTRATIONS}

Plate 1. Lithologic and gamma-ray logs of Big Stone Gap Member of Chattanooga Shale and associated units exposed along Powell River, Big Stone Gap, Wise County, Va In pocket

Figure 1. Map of Pine Mountain fault block

2. Map of Big Stone Gap, Va., showing the type section of the Big Stone Gap Member of the Chattanooga Shale

3. Photomosaic of type section of Big Stone Gap Member of Chattanooga Shale

4. Chart showing gamma-ray correlation from surface to subsurface, Wise County, Va

5. Photograph showing contact of equivalents of Sunbury and Bedford Shales at type section of Big Stone Gap Member of Chattanooga Shale, Wise County, Va

6. Sketch of deformed zone in Big Stone Gap Member, Chattanooga Shale, along Powell River, Big Stone Gap, Va

7. Photograph of contact between Big Stone Gap Member and middle gray-siltstone member of Chattanooga Shale at type section along Powell River, Big Stone Gap, Va

8. Schematic drawing of a typical thin section of shale exposed at Big Stone Gap

9. Vertical profile of section of Chattanooga Shale at Big Stone Gap, Wise County, Va 


\section{TABLES}

TABLE 1. Petrographic composition of Chattanooga Shale, Big Stone Gap, Va

2. Maximum grain size in thin sections of the Chattanooga Shale, Big Stone Gap, Wise County, Va 


\title{
STRATIGRAPHY OF THE CHATTANOOGA SHALE (UPPER DEVONIAN AND LOWER MISSISSIPPIAN) IN VICINITY OF BIG STONE GAP, WISE COUNTY, VIRGINIA
}

\author{
By ROY C. KePFERle, PAUl EdWIN POTTER, ${ }^{1}$ and WAYNE A. PRYOR ${ }^{1}$
}

\section{ABSTRACT}

Floods on the Powell River in April 1977 exposed a classic section of the Chattanooga Shale (Devonian and Mississippian) in Big Stone Gap, Va. Within a month after the flood, the authors examined the section, collected samples, logged the radioactivity, measured joints, and described the lithology. The gamma-ray log of the section closely resembles the gamma-ray profile of the upper one-half of the Chattanooga Shale sequence in a nearby well, Columbia Gas Transmission Corp., Pennsylvania-Virginia Corp., farm well no. 20338, from which an oriented core has been taken by the U.S. Department of Energy's Morgantown Energy Research Center.

Mapped surface units were compared and correlated with units identified in greater detail on the gamma-ray log from the well. Units of the Big Stone Gap Member in this section are equivalent to the Sunbury Shale (Lower Mississippian), the Bedford Shale (Upper Devonian and Lower Mississippian), and the Cleveland Member of the Ohio Shale (Upper Devonian). The middle gray-siltstone member of the Chattanooga Shale of the surface mapping includes the equivalents of the Three Lick Bed of the Ohio Shale and of the upper and middle parts of the Huron Member of the Ohio Shale. The Foerstia zone was found in the outcrop samples after an intensive search of the interval, which was shown by the gamma-ray log to correspond to the interval in the core where Foerstia were found.

Composition, maximum grain size, and lamination were examined in 30 thin sections of the exposed rocks. Quartz and feldspar, clay, coarse micaceous minerals, organic matter, pyrite, chert, and rock fragments were recognized in decreasing abundance. Coarsest grains of quartz and feldspar range in size from fine sand to silt. Two types of lamination recognized in thin section are distinct silt laminae and distinct organic laminae.

Joint orientation from 76 measurements show perpendicular bimodality. One mode parallels the present structural strike. Slight variations are evident in the differing rock types.

\section{INTRODUCTION}

Gas production from the Devonian shale sequence of the Appalachian basin may be best improved by relating the engineering, petrologic, and geochemical properties of the shale to its internal stratigraphic units. The internal stratigraphy of the shale sequence provides the only

\footnotetext{
${ }^{1}$ Professor of Geology, H. N. Fisk Laboratory of Sedimentology, University of Cincinnati, Cincinnati, Ohio 45221.
} 
fundamental framework to which the above properties can be related and understood-both locally and for the entire basin.

This paper is a step toward a better understanding of the internal stratigraphy of the black shale of the Pine Mountain overthrust block in the central Appalachians; information is based upon an exceptionally good outcrop at Big Stone Gap, Va., and a recently drilled oriented core, both in Wise County (fig. 1). The outcrop at Big Stone Gap is more than $600 \mathrm{ft}$ long, is almost completely exposed, and is little weathered because it lies on the eroding bank of the Powell River (fig. 2). Because of its length, accessibility, and freshness of exposed rock, this outcrop is certainly the very best place to see the stratigraphy of the upper part of the shale in the overthrust block. As a reference section, it is worthy of careful stratigraphic, petrologic, and paleontologic study.

Previous descriptions of the section were made by Ulrich and Stose (Stose, 1923, p. 40-53); Swartz (1927, p. 492-493, and 1929, p. 433-434); and Roen, Miller, and Huddle (1964, p. B46-B47); the latter provided a summary of all the earlier work. Webb and Nunan (1972, p. 193 and 196) cited other published descriptions of the Devonian-Mississippian shale sequence in Wise County and in Lee County, Va., to the southwest (p. 87). The section is also shown graphically in regional correlations by Kindle (1912, pl. 1) and Butts (1940, pl. 45). Much earlier, the Devonian rocks in the Big Stone Gap section were casually mentioned by Campbell (1893). An early geologic map of the area was made by Stevenson (1881).

Miller (1965) completed a geologic map (scale 1:24,000) of the Big Stone Gap quadrangle and recognized three units of the Chattanooga Shale that have a total thickness of about $900 \mathrm{ft}$ thick. Geologic maps of nearby areas, at the same scale and showing Chattanooga Shale, although not always named specifically, include those of the Stickleyville (Harris and Miller, 1963), Keokee (Miller and Roen, 1971), Benham and Appalachia (Froelich and Stone, 1973), and Duffield (Harris and Miller, 1958) quadrangles.

The nomenclature and age of the black shale as a whole in the Big Stone Gap area was last reviewed by Roen and others (1964). Additional important publications on the stratigraphy of Big Stone Gap shale are stratigraphic cross sections by Wallace, Roen, and de Witt (1977), Roen, Wallace, and de Witt (1978), and West (1978). These sections extend from southwestern New York almost to Cumberland Gap, and the publications are pioneering efforts to correlate the many different stratigraphic units of the Devonian shale sequence of the Appalachian basin. Another useful regional cross section (Kepferle and others, 1978) extends from near Chillicothe, Ohio, into Scott County, Va. These cross sections are essential to an understanding of the 


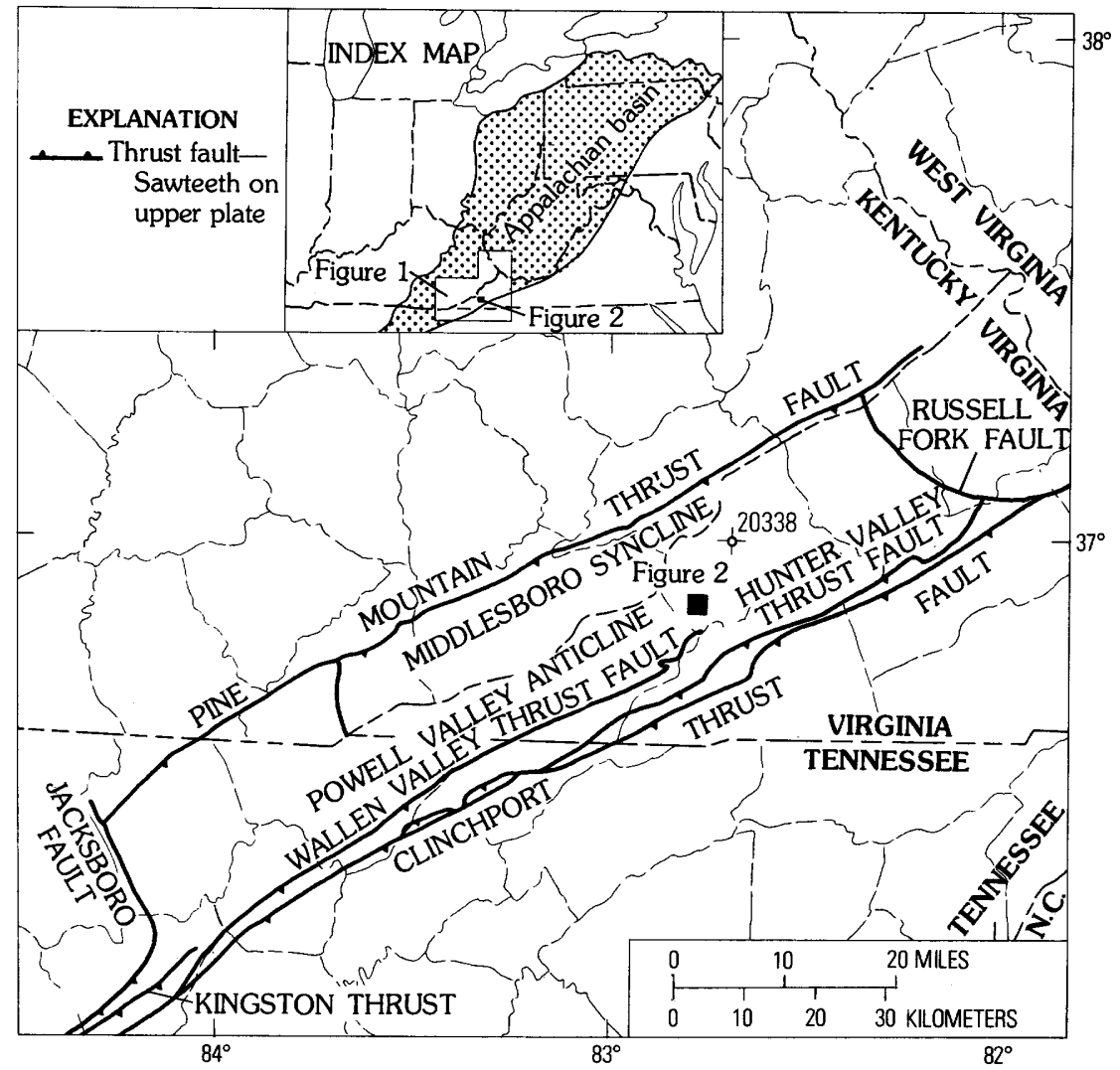

FIgURE 1.-Pine Mountain fault block showing location of type section of Big Stone Gap Member of Chattanooga Shale (fig. 2) and site of Columbia Gas Transmission Corp., Pennsylvania-Virginia Corp., farm well no. $20338(\phi)$, and related structural features, Kentucky, Virginia, and Tennessee.

regional internal stratigraphy of the Big Stone Gap shale. All four sections are internally consistent across the Appalachian basin, and constitute a major advance in our stratigraphic knowledge of the shale sequence.

\section{ACKNOWLEDGMENTS}

This work was completed with the support of the U.S. Department of Energy in contract with the University of Cincinnati and the U.S. Geological Survey. The freshness of the outcrop was brought to our attention by Donald Le Van, William Kelly, and Eugene Rader of the Virginia Division of Mineral Resources. All photographs were taken by Roy Kepferle. Helpful suggestions on subsequent visits to the outcrop 


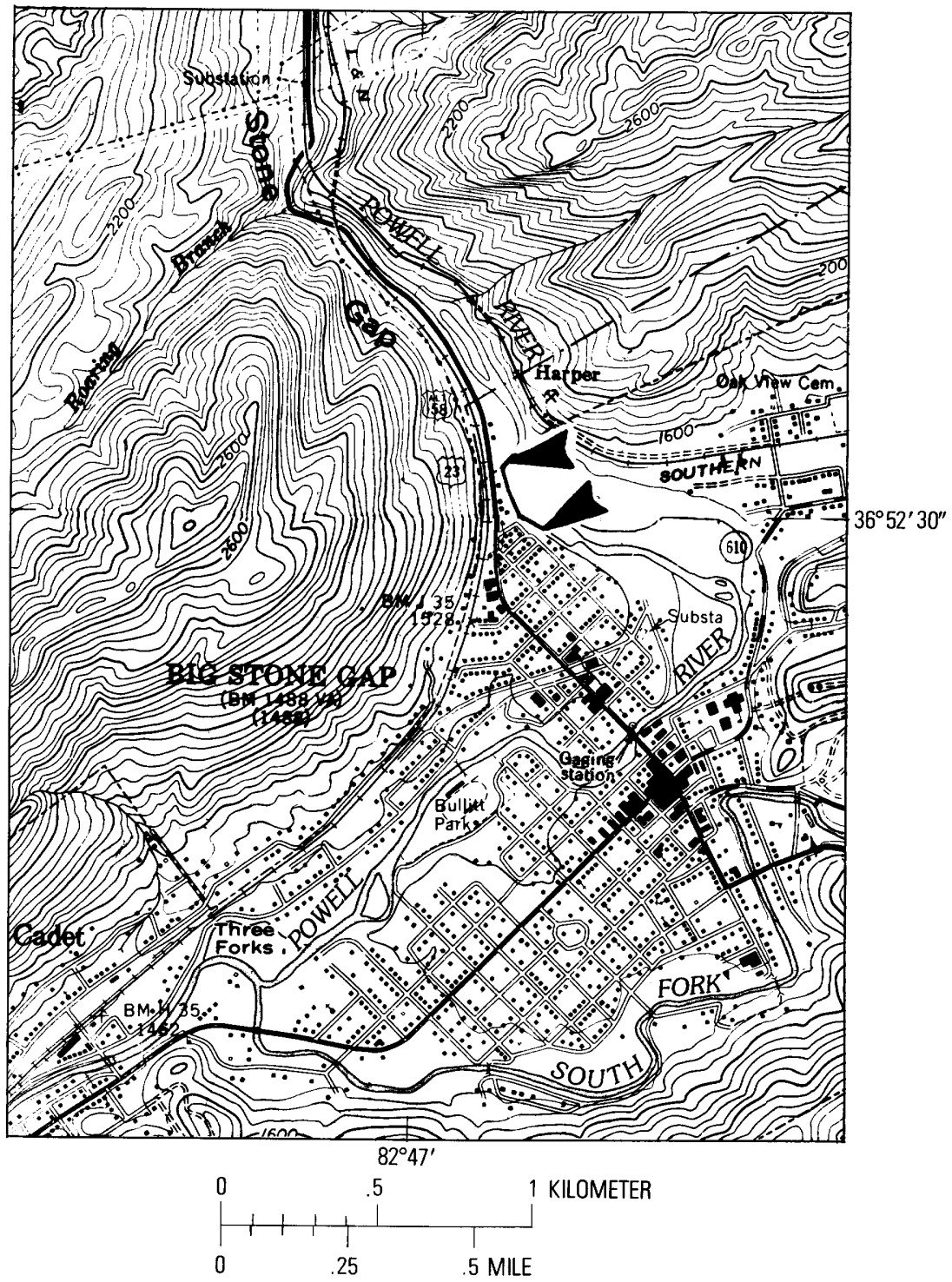

Figure 2. - Big Stone Gap, Va. $(1: 24,000)$, showing the type section of the Big Stone Gap Member of the Chattanooga Shale. Section, indicated by heavy black line between two arrowheads, is on west side of Powell River; top of section is at north end of line. 
were made by John Clendening and colleagues of Amoco Production Co., and Ronald Broadhead of the University of Cincinnati. James D. Williams, University of Cincinnati, compiled the originals for the illustrations. The report in its present form would not have been possible without the help of each of those acknowledged above.

\section{DESCRIPTION AND INTERPRETATION OF THE SECTION}

To delineate and define local map units, Roen, Miller, and Huddle (1964) redefined the Big Stone Gap Member of the Chattanooga Shale from exposures at Big Stone Gap, Wise County, Va. The purpose of this report is not to further redefine the units exposed; we recognize the validity of the definition by Roen and others (1964). Our purpose in reexamining the section is to enable correlation of the Big Stone Gap Member with the upper part of the Devonian shale sequence elsewhere in the basin.

\section{METHOD}

The section was measured, described, and sampled, and a radioactivity survey was completed by a seven-member team in May $1977^{2}$. Additional observations and photographs of the section were made on four subsequent visits by one or more of the members. The section was sampled at intervals of 5 feet; these samples provide the basis for further laboratory and thin-section study. W. A. Pryor and E. N. Wilson measured the radioactivity of the section at 1-foot intervals; they used a portable scintillometer (Mt. Sopris Model SC 131$)^{3}$, and followed the method outlined by Ettensohn and others (1979). B. R. Long, using a standard Brunton compass for strike and dip, measured joint sets. The results of the field measurements are shown on plate 1. Graphic comparison with full-scale wire-line logs from oil and gas exploration test holes is facilitated by plotting all data at $1 \mathrm{inch}=20 \mathrm{ft}$ vertically, the scale of the section.

Thin sections of 30 samples from the section at Big Stone Gap were cut normal to the bedding and were studied by T. V. Stenbeck using a Zeiss Model II Pol Photomicroscope. On each slide, 200 compositional counts were made at magnifications of $\times 500$ to $\times 800$. The longest dimension of 10 of the largest quartz and feldspar grains were measured, and the type of thickness of the lamination was recorded.

\footnotetext{
2 Paul D. Lundegard, Frederick J. Schauf, and Neil D. Samuels, all of the University of Cincinnati, Cincinnati, Ohio 45221, assisted the authors in the preparation of this report.

3 Any trade names in this publication are used for descriptive purposes only and do not constitute endorsement by the U.S. Geological Survey.
} 


\section{DESCRIPTION}

The exposure is on the east flank of the Middlesboro syncline near the crest of the northeast-plunging Powell Valley anticline. The rocks dip $35^{\circ}$ to $50^{\circ} \mathrm{NW}$. and strike N. $40^{\circ} \mathrm{E}$.

Near Big Stone Gap, the Chattanooga Shale consists of three members which, in descending order, are the Big Stone Gap Member, the middle gray-siltstone member, and the lower black-shale member. They have an aggregate thickness of about $900 \mathrm{ft}$ (Miller, 1965). Our preliminary examination of the section at Big Stone Gap indicated that more rocks were recently exposed than had been seen by Roen and others in 1964. Exposures, in fact, were particularly good because recent high water along the Powell River had scoured the outcrop and removed litter. A photomosaic index (fig. 3) gives a slightly distorted overview of the exposure. The upper part of the section on the right in the photomosaic is marked by a pine tree growing on ledges in the Price Siltstone. Closeup photographs and drawings supplement the mosaic and illustrate additional lithic distinctions.

The correlation of the surface and subsurface stratigraphic units on plate 1 was established by comparison of the detailed gamma-ray log of the surface section with the gamma-ray log of the nearby well, taken with the cooperation of the U.S. Department of Energy, Morgantown Energy Technology Center (DOE-METC), Morgantown, W. Va. (see fig. 4).

The relative resistance of the section to weathering is plotted by an uneven line along the right margin of the lithic column. A visible correlation can be made between zones of high radioactivity and dark shale resistant to weathering; by inference, both can be related to organic content somewhat greater than that in the lighter colored shale beds below, which are less resistant to weathering.

The stratigraphic units shown on the wire-line gamma-ray log of the Columbia Gas Transmission Corp., Pennsylvania-Virginia Corp. farm well no. 20338, correlate with the units shown in the cross section extending across the southern part of the Appalachian basin from southern Ohio to western Virginia (Kepferle and others, 1978). This cross section contains some units correlated by additional sections longitudinally along the western, central, and eastern part of the Appalachian basin (Roen and others, 1978; Wallace and others, 1977; West, 1978). These correlations are based mainly on radioactivity of the shales but are tied to lithologic sections at the surface in Virginia, southern Ohio, Kentucky, and New York, where named rock stratigraphic units can be identified. The units recognized as equivalents of the Big Stone Gap Member are discussed below. They include, in descending order: the Sunbury Shale (Lower Mississippian), the Bedford Shale (Devonian and Mississippian), and the Cleveland 


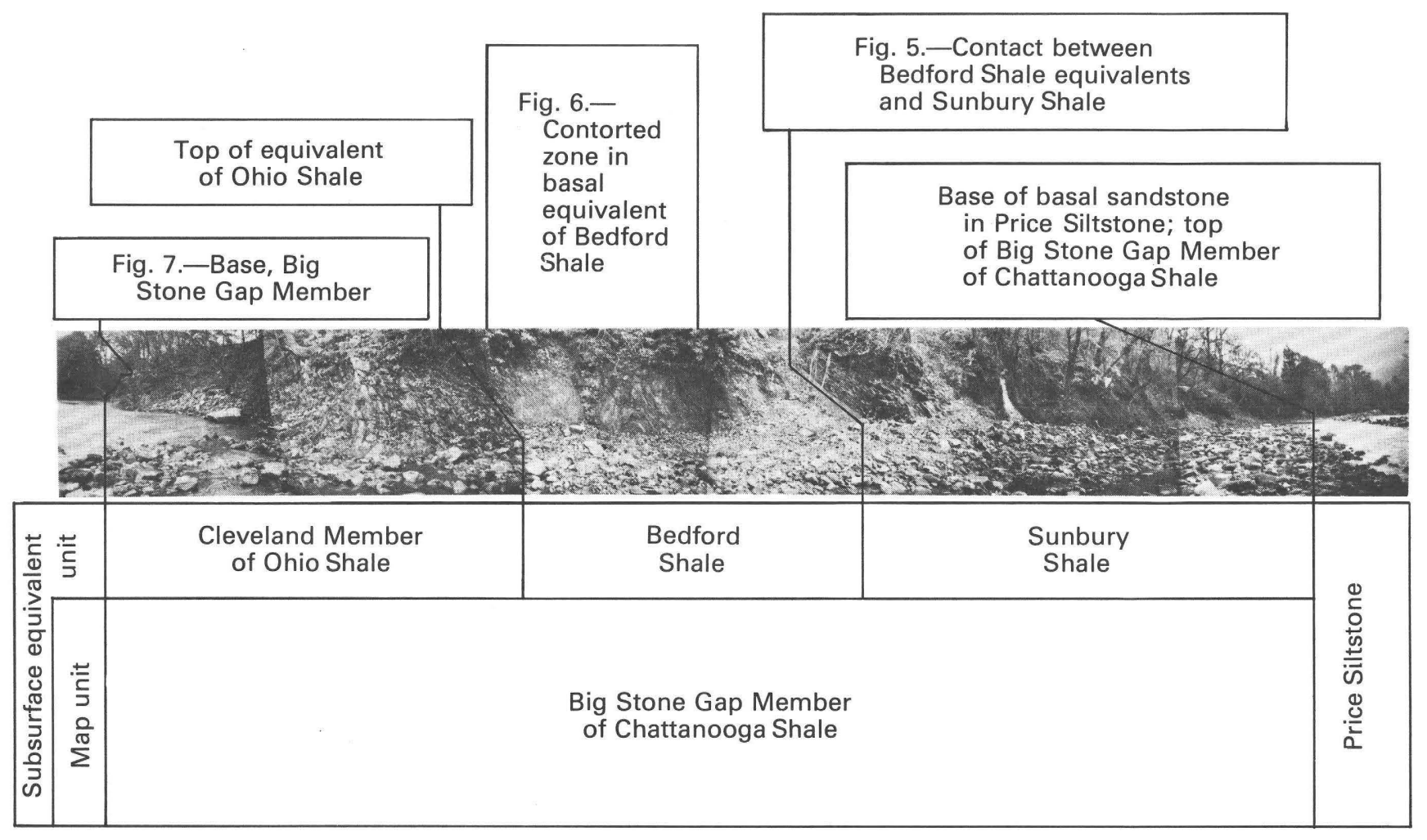

FIGURE 3.-Photomosaic index of type section of Big Stone Gap Member of Chattanooga Shale showing locations of detailed illustrations and subsurface equivalents from figure 4. 


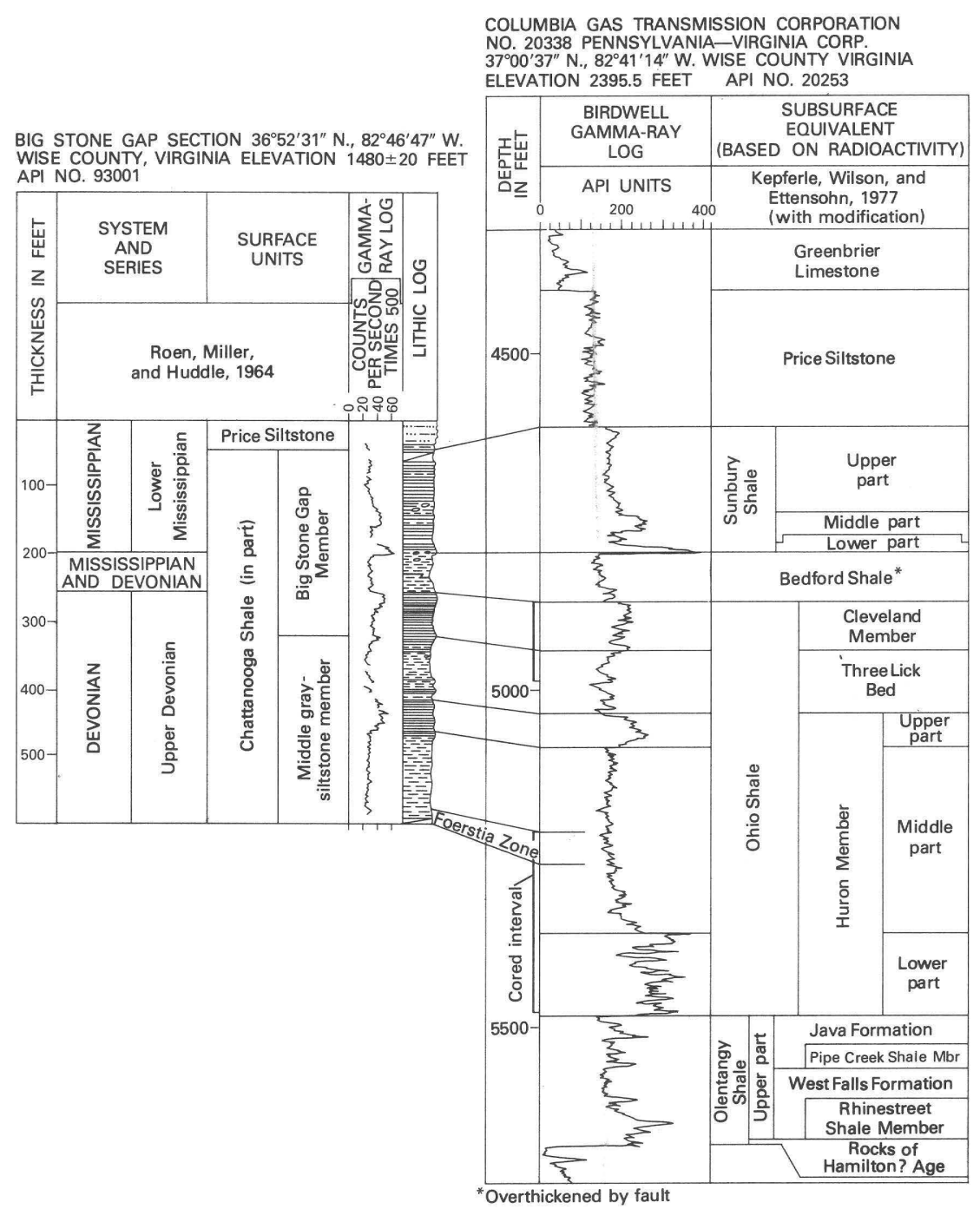

Figure 4.-Gamma-ray correlation from surface to subsurface, Wise County, Va.

Member of the Ohio Shale (Upper Devonian). In the middle graysiltstone member of the Chattanooga Shale, we found equivalents of the Three Lick Bed (Provo and others, 1978) and the upper part of the Huron Member of the Ohio Shale. These correlations agree with the age designations from conodont identifications by Huddle (Roen and others, 1964, p. B47). 


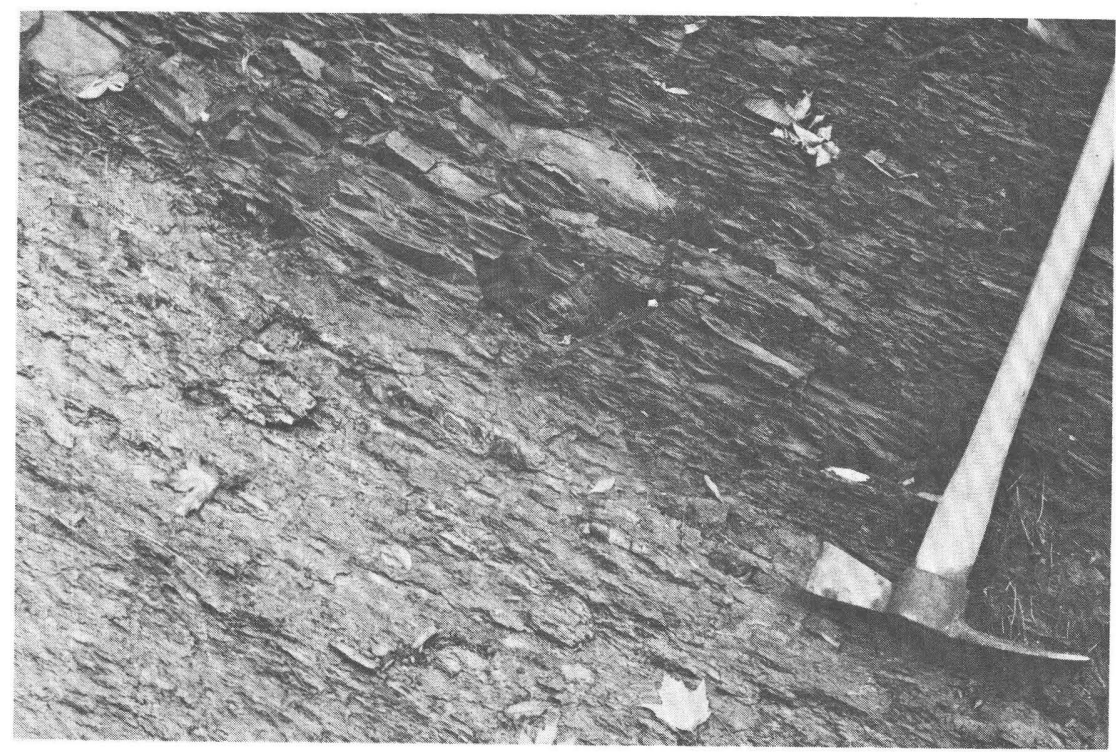

FIGURE 5.-Contact of equivalents of Sunbury (above) and Bedford (below) Shales at type section of Big Stone Gap Member of Chattanooga Shale, Wise County, Va. Bed of phosphatic nodules, shown at pick head, marks the contact.

The correlations also agree with those of E. O. Ulrich (Stose, 1923, p. 47 ) in regard to the Big Stone Gap shale "correlating it with the Sunbury and Cleveland shales of Ohio *** From his study of the shales at Big Stone Gap he has concluded, on the evidence of fossil content, lithologic characters, and sequence of beds, that the black shale comprising the upper 120 feet of his section quoted above is Sunbury; 30 feet of underlying reddish shale may be Bedford; 170 feet of dark shale containing linguloids, discinoids, a few conodonts, plant remains, and fish scales and spines is of Cleveland and Huron age."

In Ulrich's section at Big Stone Gap (Stose, 1923, p. 47) referred to in the quotation above, Ulrich noted that the Sunbury Shale contains phosphatic nodules and pyritiferous layers. We find this phosphatic zone at the top of unit 17 (pl. 1; see also fig. 5). It marks the base of the highly radioactive deflection on the gamma-ray curve shown for the lower part of the Sunbury Shale (fig. 4 and pl. 1).

\section{SUNBURY SHALE}

The Sunbury Shale, from its gamma-ray curve, can be divided into lower, middle, and upper parts (pl. 1 and fig. 4). The lower part of the Sunbury Shale is commonly the most radioactive unit in the entire black-shale sequence in eastern Kentucky and provides an excellent 
datum for correlation in the western part of the Appalachian basin (see pl. 1 and fig. 4). The zone of highest radioactivity (unit 18, pl. 1) in the Sunbury occurs just above the horizon of phosphate nodules that marks the top of the Bedford Shale. Unit 18 is unit 10 of Roen and others (1964, p. B46), from which Huddle identified the conodont assemblage he assigned to the Lower Mississippian rocks (Roen and others, p. B47).

Subsurface cross sections that include the western extension of the interval between the Price Siltstone and the base of the Sunbury Shale show that the interval of low radioactivity above the basal part of the Sunbury thins to the west. The radioactivity of the shale in the interval also increases westward irregularly from top to bottom, becoming nearly as intense as that of the basal part of the Sunbury. Because this increase is gradual and continuous in the section at Big Stone Gap and in the section penetrated in well no. 20338, we regard the entire sequence of rocks between the Price Siltstone and the distinct radioactive unit in the basal part of the Sunbury as the Sunbury Shale in both the well and the outcrop section. To the east, faulting interrupts continuity and precludes tracing the Sunbury with certainty. The uppermost 7 feet of the section immediately below the Price Siltstone is olive-gray and light-olive-gray shale (unit 30, pl. 1) and may be equivalent to the unnamed shale of the Price Siltstone (Ceres Member of Bartlett, 1974, p. $890 \mathrm{~B})$. This shale cannot be identified with certainty on the gammaray log of well no. 20338.

\section{BEDFORD SHALE AND CONTORTED ZONE}

Medium-gray to greenish-gray shale, typical of the Bedford Shale, makes up most of units 15 through 17 (pl. 1). A few siltstone interbeds may represent a lithology more typical of the Berea Sandstone, but no discrete sandstone or siltstone group of beds is evident either here or from the equivalent interval on the gamma-ray log of well no. 20338.

Several faults cut the section along the exposures at Big Stone Gap. Some of these show small displacement, as in units 21 and 2 (pl. 1); others show little to considerable disturbance of bedding, as in units 14 and 15 (pl. 1), respectively. The contorted bedding of units 14 and 15 (fig. 6) was also noted in the section measured by Roen and others (1964, p. B46, units 8 and 9). An examination of the formation density curve of the Pennsylvania-Virginia Corp. farm well no. 20338 indicates that a structural displacement, including a thin sliver of radioactive shale as in the outcrop section, occurs at the same stratigraphic position. This apparent correlation of bedding-plane slip across a distance of more than 10 miles corroborates thin-skinned deformation described in the south in the Valley and Ridge province by Harris and Milici (1977, p. 5-8). 


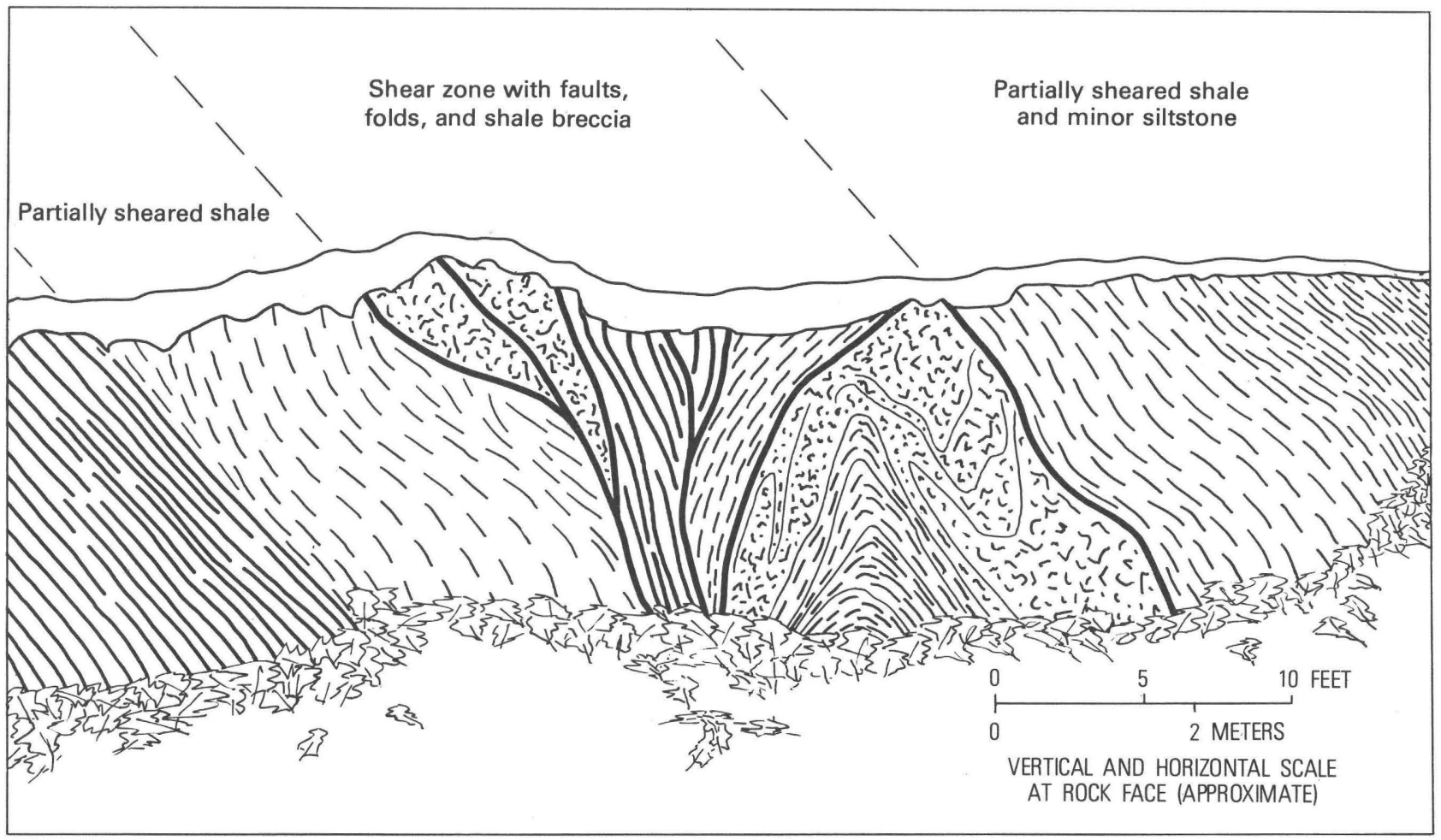

FiguRE 6.--Deformed zone in Big Stone Gap Member, Chattanooga Shale, along Powell River, Big Stone Gap, Va. (units 14 and 15 pl. 1). Bold lines indicate faults; heavy lines indicate dark shale of unit 14, equivalent to part of the Cleveland Member of Ohio Shale; lighter dashed lines indicate lighter shale and siltstone, equivalent to part of the Bedford Shale. Sketched by J. D. Williams from photograph. 


\section{CLEVELAND MEMBER AND THREE LICK BED OF OHIO SHALE}

In the base of the Big Stone Gap Member, which is the equivalent of the Cleveland Member of the Ohio Shale, is the thickest homogeneous unit of black shale (unit 14, pl. 1). The top of the underlying unit is marked by a sequence of interbedded greenish-gray and brownishblack shale that is correlated with the Three Lick Bed of Provo, Kepferle, and Potter (1978) on the basis of lithology, stratigraphic position, and gamma-ray signature. These are the first beds of greenishgray shale in the sequence below the equivalent of the Bedford Shale. Units 10 and 12, which lack significant black shale beds, may be the Chagrin Shale (see fig. 7 and pl. 1).

\section{HURON MEMBER OF OHIO SHALE}

Lower in the section, the upper part of the Huron Member of the Ohio Shale is obscure but identifiable on the basis of lithology, position, and gamma-ray signature (fig. 4 and pl. 1). The least radioactive unit in the middle gray-siltstone member is the equivalent of the middle part of the Huron Member of the Ohio Shale. We confirmed the correlation by

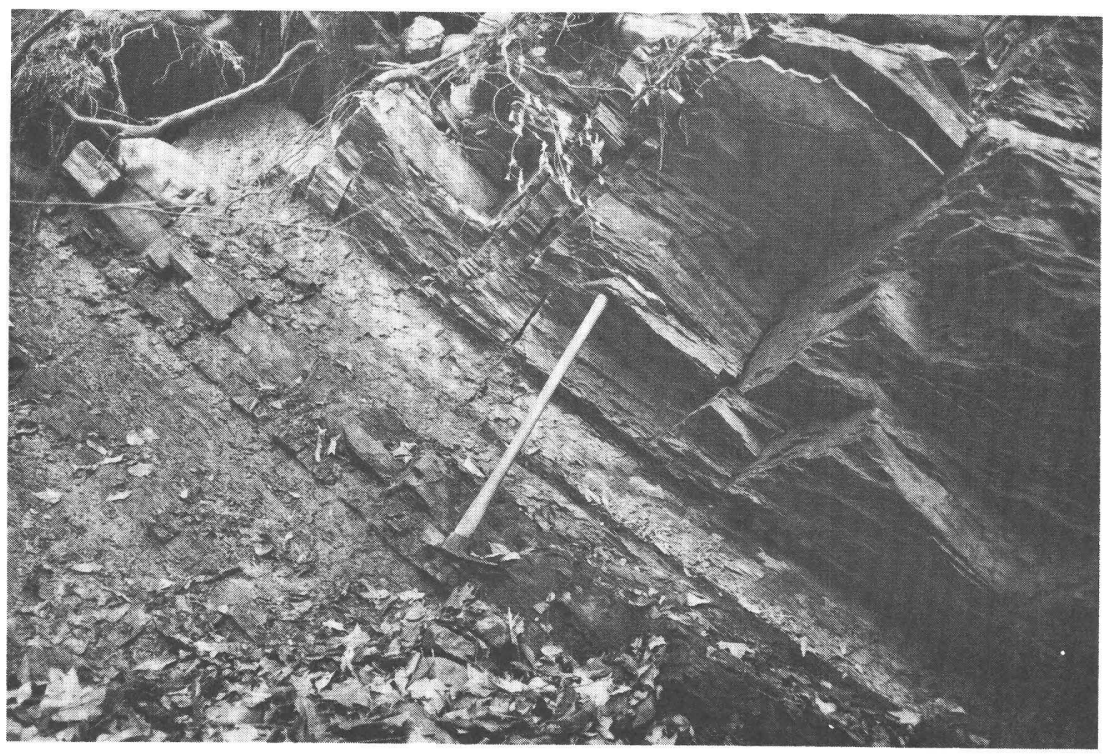

Figure 7.- Photograph of contact between Big Stone Gap Member (above) and middle gray-siltstone member (below) of Chattanooga Shale at type section along Powell River, Big Stone Gap, Va. Respective equivalent rocks in Kentucky and southern Ohio are the Cleveland Member and the Three Lick Bed of the Ohio Shale. Contact marked by color change in upper part of pick handle. 
finding fossils of the alga Foerstia in samples collected from near the base of the outcrop section. Foerstia has been recognized as an important flora in the shale (Schopf and Schwietering, 1970; Schwietering and Neal, 1978). Foerstia samples from the Big Stone Gap section came from near water level along the river and were found after the Foerstia zone had been identified in the core of well no. 20338 by J. F. Schwietering (written commun., 1977). The gamma-ray correlation between the outcrop and the well helped us in finding the beds containing Foerstia at Big Stone Gap.

\section{JOINTS}

Strike directions of joints were plotted as rose diagrams showing the relative percentages of strike directions for given rock intervals (pl 1). In addition, a composite rose diagram was plotted from the total 79 strike measurements taken in the section.

The roses show conspicuous jointing modes at N. $45^{\circ}$ E., and E. $30^{\circ}$ W. The joints trending N. $45^{\circ} \mathrm{E}$. parallel the structural strike of the west flank of the Powell Valley anticline. Both sets may be release or tension joints: the set striking northwest may be related to the plunging nose of the Powell Valley anticline, and the set striking northeastsouthwest may be related to the stress release of the Pine Mountain overthrust sheet, perpendicular to the northwestward direction of tectonic transport (Billings, 1972, p. 168). More careful regional study of the joints is needed to confirm the persistence of these two modes and the validity of the explanation presented above.

Minor offset of the joint sets in vertical sequence may be related to slight differences in lithology, as noted by G. W. Colton (written commun., 1978), elsewhere in the Appalachian basin.

\section{PETROLOGY}

\section{By Thomas V. STENBECK ${ }^{4}$}

The results of the petrographic analyses of thin sections from Big Stone Gap are shown in stratigraphic sequence in table 1.

\section{COMPOSITION AND TEXTURE}

In decreasing abundance, recognizable silt-size inorganic components are: quartz, mica, pyrite, carbonate rocks, rock fragments, and chert. Clay-size matrix, chiefly illite and chlorite, may include some quartz. Organic matter includes unidentified structureless shreds and spores.

${ }^{4}$ Department of Geology, University of Cincinnati, Cincinnati, Ohio 45221. 
TABLE 1.-Petrographic composition of Chattanooga Shale, Big Stone Gap, Va.

[Composition in percent]

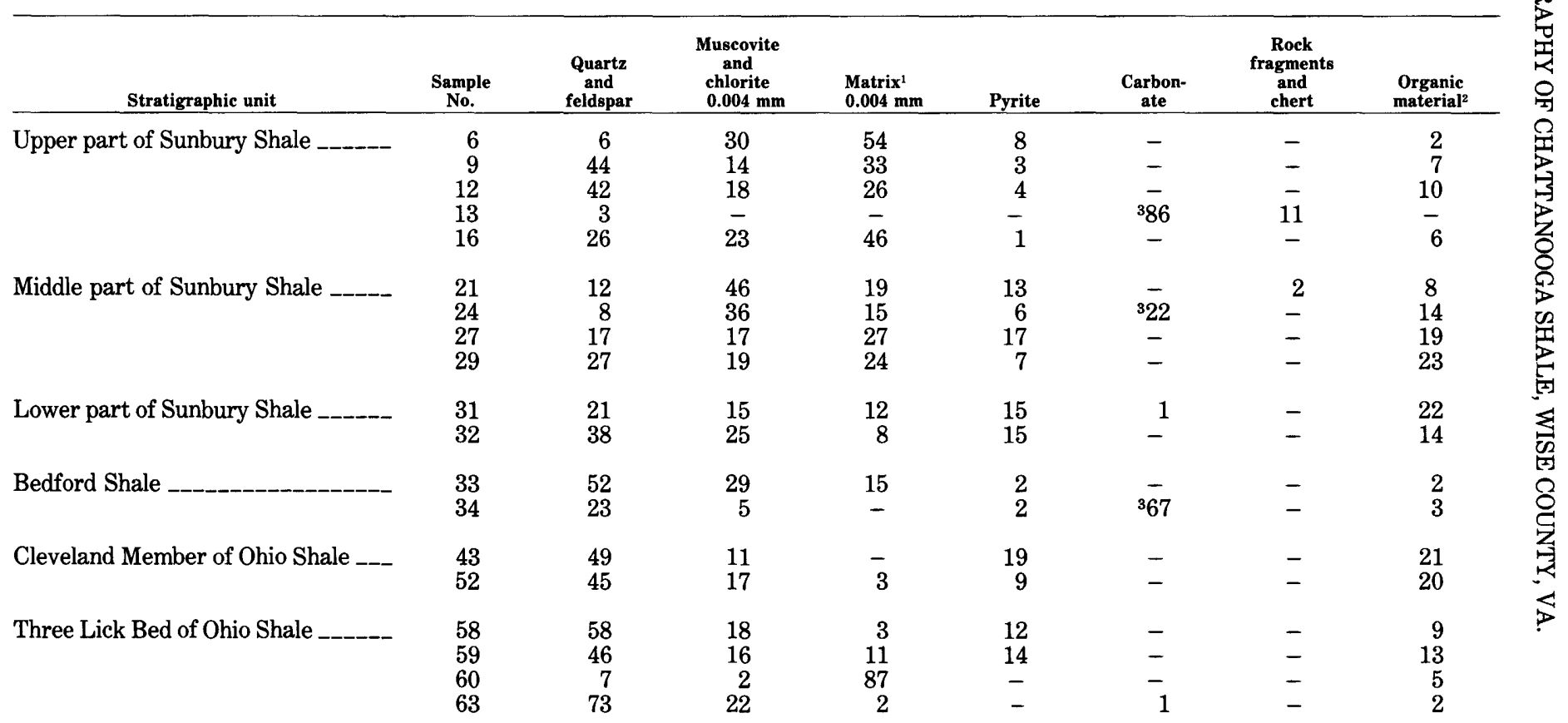


Upper part of Huron Member of Ohio Shale

$\begin{array}{ll}69 & 40 \\ 71 & 41 \\ 73 & 80 \\ 79 & 60 \\ 82 & 36\end{array}$

$\begin{array}{rrrr}1 & - & - & 10 \\ 1 & - & - & 4 \\ 3 & - & - & 2 \\ 10 & - & - & 7 \\ 15 & - & - & 20\end{array}$

Middle part of Huron Member of Ohio Shale

$\begin{array}{rr}88 & 5 \\ 91 & 4 \\ 94 & 3 \\ 96 & 4 \\ 100 & 4 \\ 108 & 35\end{array}$

53

44

\section{AVERAGE}

14
22
34
24
25
30

4
15
16
12
9
14
19

10
11
4
13
13

$\begin{array}{rr}- & 18 \\ - & 8 \\ - & 12 \\ - & 11 \\ - & 13 \\ - & 12\end{array}$

1 Includes illite, chlorite, and other unidentified clay-size minerals.

${ }^{2}$ Mainly unidentified shreds and some spores.

Tr. 


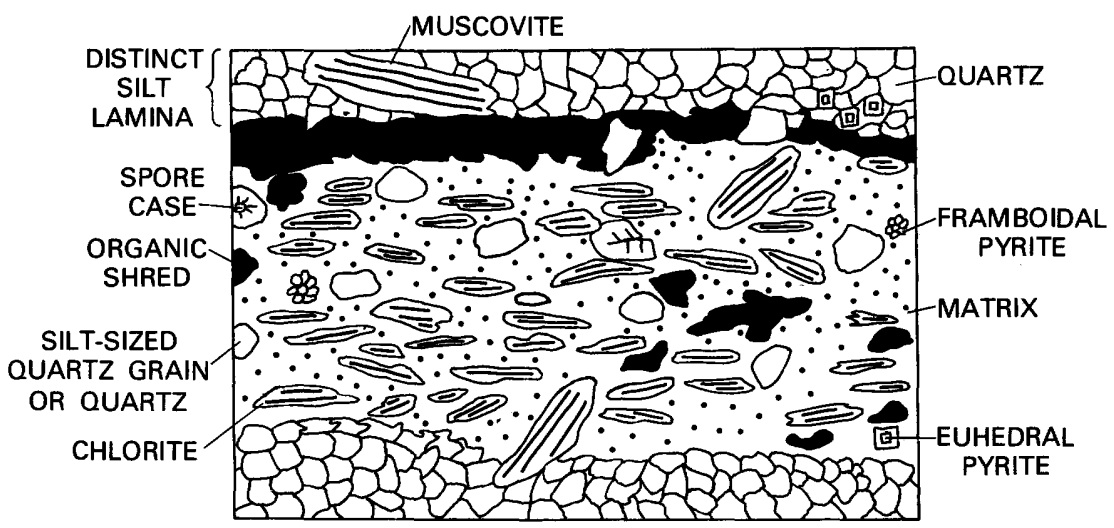

FIGURE 8. - Schematic drawing of a typical thin section of shale exposed at Big Stone

Gap showing the appearance and distribution of the principal components $(\times 600)$.

Silt-size quartz and feldspar average 37 percent of the composition and occur in distinct laminae and as dispersed grains (fig. 8). Feldspar averages less than 1 percent and is chiefly plagioclase. Coarse micaceous minerals include both muscovite and chlorite, average 19 percent, and occur as ragged elongate grains oriented roughly parallel to bedding (fig. 8). Muscovite, which is generally larger grained, averages 5 percent or less. Chlorite makes up the remainder of the mica grains.

Pyrite averages 8 percent, and occurs as single euhedral crystals, or as framboidal aggregates composed of euhedral crystals. Carbonate minerals are rare, but they are the principal components from three samples of concretions. They occur as subspherical particles 5-10 microns in diameter and also as $0.10-\mathrm{mm}$-diameter ovoid patches, which appear to be filling preexisting voids. Chert and rock fragments are sparse. Chert occurs as silt-sized microcrystalline grains; rock fragments include grains of chlorite schist, phyllite, and shale. The matrix, which averages 8 percent, is chiefly illite and chlorite. Matrix may also include some clay-sized quartz.

Organic matter, which averages 11 percent, is in two forms. The most abundant form is disseminated structureless shreds, which may be concentrated as laminae. The second form is spore and spore-case material with walls as thick as $0.01 \mathrm{~mm}$, some of which show the original cellular structure.

The maximum grain size gives a rapid means of comparing grain sizes of fine-grained sediment. The maximum size of the quartz grains was obtained by scanning each slide and averaging the diameter of the ten largest grains. The maximum grain size for the Big Stone Gap sec- 
tion ranges from $0.014 \mathrm{~mm}$ to $0.087 \mathrm{~mm}$ and averages $0.040 \mathrm{~mm}$ in diameter (table 2).

Coarsest grains are in the range of very fine sand and occur in the Sunbury Shale and the Bedford Shale, and in one sample of the Cleveland Member of the Ohio Shale (fig. 9).

\section{LAMINAE}

The thin sections from the Big Stone Gap section show two types of lamination. One type is defined by silt and ranges from discontinuous layers of quartz and feldspar, one or two grains thick to continuous layers as much as $5 \mathrm{~mm}$ thick. The other type is defined by concentrations of layered organic matter. Continuous thick silt laminae are found in the basal part of the Bedford Shale, in the Three Lick Bed, and the Foerstia zone of the middle part of the Huron Member of the Ohio Shale. Continuous thin laminae are found throughout the Ohio Shale, and discontinuous laminae are found in samples from the Bedford Shale and the uppermost part of the Sunbury Shale.

Organic laminae are present mainly in the Cleveland Member of the Ohio Shale and in the Sunbury Shale.

TABLE 2. - Maximum grain size in thin sections of the Chattanooga Shale, Big Stone Gap, Wise County, Va.

[Thomas V. Stenbeck, analyst]

\begin{tabular}{|c|c|c|c|}
\hline $\begin{array}{c}\text { Sample } \\
\text { No. }\end{array}$ & $\begin{array}{c}\text { Grain size }^{1} \\
\text { (in } \mathrm{mm} \text { ) }\end{array}$ & $\begin{array}{c}\text { Sample } \\
\text { No. }\end{array}$ & $\begin{array}{c}\text { Grain size }{ }^{1} \\
\text { (in mm) }\end{array}$ \\
\hline 1 & 0.046 & 46 & 0.037 \\
\hline 2 & .021 & 49 & .038 \\
\hline 6 & .020 & 52 & .048 \\
\hline 9 & .014 & 54 & .043 \\
\hline 12 & .023 & 57 & .064 \\
\hline 13 & .022 & 58 & .050 \\
\hline 16 & .022 & 59 & .042 \\
\hline 17 & .038 & 60 & .019 \\
\hline 21 & .034 & 61 & .028 \\
\hline 22 & .029 & 63 & .025 \\
\hline 24 & .087 & 65 & .056 \\
\hline $\begin{array}{l}24 \\
27\end{array}$ & .042 & 69 & .046 \\
\hline 29 & .028 & 71 & .028 \\
\hline 31 & .032 & 73 & .055 \\
\hline 32 & .035 & 79 & .049 \\
\hline 33 & .065 & 82 & .037 \\
\hline 34 & .060 & 88 & .043 \\
\hline $\begin{array}{l}34 \\
38\end{array}$ & .069 & $\begin{array}{l}80 \\
91\end{array}$ & .042 \\
\hline \multirow{4}{*}{$\begin{array}{l}41 \\
43\end{array}$} & .049 & $\begin{array}{l}91 \\
94\end{array}$ & .033 \\
\hline & .054 & 96 & .044 \\
\hline & & 100 & .049 \\
\hline & & $\begin{array}{l}102 \\
108\end{array}$ & $\begin{array}{l}.030 \\
.033\end{array}$ \\
\hline
\end{tabular}

${ }^{1}$ Average of 10 coarsest quartz grains in thin section. 


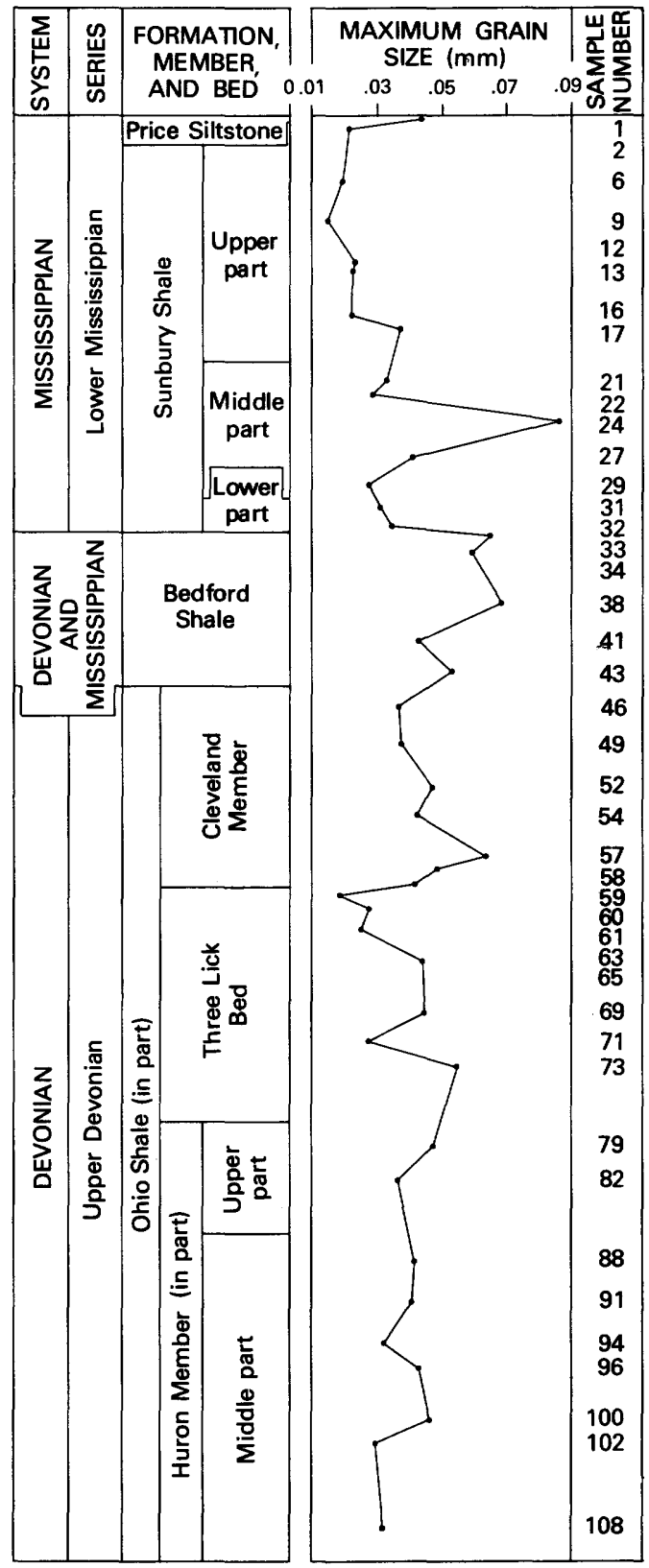

FIGURE 9. - Vertical profile of section of Chattanooga Shale at Big Stone Gap, Wise County, Va., showing variation of maximum grain size in recognized subsurface equivalent stratigraphic units. (Thomas V. Stenbeck, analyst.) 


\section{CONCLUSIONS}

1. The Big Stone Gap Member of the Chattanooga Shale is a valid mappable unit in western Virginia.

2. The subdivisions traceable in the subsurface through correlation on wire line logs are valid and should be used where they can be recognized. The Big Stone Gap section shows that these subdivisions can be recognized in excellent exposures, even though they may not be mappable at the surface because of excessive cover by alluvium, colluvium, and vegetation.

3. In addition to stratigraphic position, lithology, and fossil content, the gamma-ray log obtained by means of a scintillometer on good exposures is a very useful adjunct to correlation between the surface and subsurface.

4. Foerstia provides a useful biostratigraphic marker zone in rocks equivalent to the Huron Member of the Ohio Shale (Upper Devonian).

5. Joint orientation is bimodal; one mode parallels the tectonic strike and the other is perpendicular to tectonic strike.

\section{REFERENGES CITED}

Bartlett, C. S., Jr., 1974, Anatomy of the Lower Mississippian delta in southwestern Virginia: Dissertation Abstracts International, v. 35, no. 2, p. 890B.

Billings, M. P., 1972, Structural geology (3d ed.): Englewood Cliffs, N. J., Prentice-Hall, Inc., $606 \mathrm{p}$.

Butts, Charles, 1940, Geology of the Appalachian valley in Virginia, Part 1, Geologic text and illustrations: Virginia Geological Survey Bulletin 52, 568 p.

Campbell, M. R., 1893, Geology of the Big Stone Gap coal field of Virginia and Kentucky: U.S. Geological Survey Bulletin 111, 106 p.

Ettensohn, F. R., Fulton, L. P., and Kepferle, R. C., 1979, Use of scintillometer and gamma-ray logs for correlation and stratigraphy in homogeneous black shales: Geological Society of America Bulletin, v. 90, part I, p. 421-423; part II, p. 828-849.

Froelich, A. J., and Stone, B. D., 1973, Geologic map of parts of the Benham and Appalachia quadrangles, Harlan and Letcher Counties, Kentucky: U.S. Geological Survey Geologic Quadrangle Map GQ-1059.

Harris, L. D., and Milici, R. C., 1977, Characteristics of thin-skinned style of deformation in the southern Appalachians, and potential hydrocarbon traps: U.S. Geological Survey Professional Paper 1018, $40 \mathrm{p}$.

Harris, L. D., and Miller, R. L., 1958, Geology of the Duffield quadrangle, Virginia: U.S. Geological Survey Geologic Quadrangle Map GQ-111.

1963, Geology of the Stickleyville quadrangle, Virginia: U.S. Geological Survey Geologic Quadrangle Map GQ-238.

Kepferle, R. C., Wilson, E. N., and Ettensohn, F. R., 1978, Preliminary stratigraphic cross section showing radioactive zones in the Devonian black shales in the southern part of the Appalachian basin: U.S. Geological Survey Oil and Gas Investigations Chart OC-85.

Kindle, E. M., 1912, The Onondaga fauna of the Allegheny region: U.S. Geological Survey Bulletin 508, $144 \mathrm{p}$. 
Miller, R. L., 1965, Geologic map of the Big Stone Gap quadrangle, Virginia: U.S. Geological Survey Geologic Quadrangle Map GQ-424.

Miller, R. L., and Roen, J. B., 1971, Geologic map of the Keokee quadrangle, VirginiaKentucky: U.S. Geological Survey Geologic Quadrangle Map GQ-851.

Provo, L. J., Kepferle, R. C., and Potter, P. E., 1978, Division of black Ohio shale in eastern Kentucky: American Association of Petroleum Geologists Bulletin, v. 62, no. 9 , p. 1703-1713.

Roen, J. B., Miller, R. L., and Huddle, J. W., 1964, The Chattanooga Shale (Devonian and Mississippian) in the vicinity of Big Stone Gap, Virginia: U.S. Geological Survey Professional Paper 501-B, p. B43-B48.

Roen, J. B., Wallace, L. G., and de Witt, Wallace, Jr., 1978, Preliminary stratigraphic cross section showing radioactive zones in the Devonian black shales in the central part of the Appalachian basin: U.S. Geological Survey Oil and Gas Investigations Chart 0C-87.

Schopf, J. M., and Schwietering, J. F., 1970, The Foerstia zone of the Ohio and Chattanooga Shales: U.S. Geological Survey Bulletin 1294-H, p. H1-H15.

Schwietering, J. F., and Neal, D. W., 1978, Occurrence of Foerstia (Protosalvinia) in Lincoln County, West Virginia: Geology, v. 6, no. 8, p. 493-494.

Stevenson, J. J., 1881, A geological reconnaissance of parts of Lee, Wise, Scott, and Washington Counties, Virginia: American Philosophical Society, Proceedings, v. 19, no. 108 , p. $219-262$.

Stose, G. W., 1923, The pre-Pennsylvanian rocks, in Eby, J. B., The geology and mineral resources of Wise County and the coal-bearing portion of Scott County, Virginia: Virginia Geological Survey Bulletin 24, p. 22-72.

Swartz, J. H., 1927, The Chattanoogan age of the Big Stone Gap shale: American Journal of Science, 5th ser., v. 14, p. 485-499.

1929, The age and stratigraphy of the Chattanooga shale in northeastern Tennessee and Virginia: American Journal of Science, 5th ser., v. 17, p. 431-448.

Wallace, L. G., Roen, J. B., and de Witt, Wallace, Jr., 1977, Preliminary stratigraphic cross section showing radioactive zones in the Devonian black shales in the western part of the Appalachian basin: U.S. Geological Survey Oil and Gas Investigations Chart OC-80.

Webb, H. W. Jr., and Nunan, W. E., 1972, Bibliography of published measured sections west of the Blue Ridge in Virginia: Virginia Division of Mineral Resources Information Circular 18, 219 p.

West, Mareta, 1978, Preliminary stratigraphic cross section showing radioactive zones in the Devonian black shales in the eastern part of the Appalachian basin: U.S. Geological Survey Oil and Gas Investigations Chart OC-86. 